\title{
Predation of waders and gulls on Lanice conchilega tidal flats in the Wadden Sea
}

\author{
Barbara Petersen', Klaus-Michael Exo ${ }^{2, *}$ \\ ${ }^{1}$ Hausdorffstrasse 309, D-53129 Bonn, Germany \\ ${ }^{2}$ Institut für Vogeliorschung 'Vogelwarte Helgoland', An der Vogelwarte 21, D-26386 Wilhelmshaven, Germany
}

\begin{abstract}
Evaluation of the importance of different benthos communities as feeding sites for waders and waterfowl is not only fundamental for understanding feeding ecology, it also enables the prediction of the effects of habitat loss. However, detailed analyses of the importance of different benthos communities for waterbirds are scarce, particularly for the German Wadden Sea. In the early 1990s, backbarrier tidal flats of the East Frisian Wadden Sea were dominated by Lanice conchilega. To estimate the relevance of those flats for waterbirds during autumn migration 1994, number, distribution and food consumption of the 7 most abundant bird species on these flats (oystercatcher, curlew, dunlin, redshank, common gull, black-headed gull, herring gull) were investigated on 2 different types of $L$ conchilega dominated flats (Lanice flat, Undulating flat). Spring tide counts throughout 1994 showed maximum bird numbers during spring (maximum: 56000 birds) and autumn migration (maximum 111000 birds). Of the 7 species examined, 4 species (oystercatcher, curlew, redshank, common gull) used both flat types in higher densities than expected. Whereas common gulls preferred the Undulating flats, oystercatchers preferred the Lanice flats. The overall number of macrozoobenthos organisms varied between 3360 and $5520 \mathrm{~m}^{-2}$ on the Undulating flat, and between 8520 and $15100 \mathrm{~m}^{-2}$ on the Lanice flat. Correspondingly, the estimated biomass ranged from 67.6 to $1.42 .3 \mathrm{~g} \mathrm{AFDW} \mathrm{m}^{-2}$ and 128.4 to $337.2 \mathrm{~g} \mathrm{AFDW} \mathrm{m}^{-2}$ (AFDW: ash free dry weight), respectively. Therefore, biomass was higher than in most other Wadden Sea areas. The most abundant species were Heteromastus filiformis, $L$. conchilega, Macoma balthica and Mytilus edulis. The overall consumption of the 7 bird species studied $(70 \%$ of all waterbirds present) decreased from $16.6 \mathrm{~g} \mathrm{AFDW} \mathrm{m}^{-2}$ in August to $12.3 \mathrm{~g} \mathrm{AFDW} \mathrm{m}^{-2}$ in October. Assuming a similar consumption for the remaining $30 \%$ of the birds, overall consumption would have ranged between 17.6 and $23.7 \mathrm{~g} \mathrm{AFDW} \mathrm{m}^{-2}$. Due to the high biomass of the standing stock, relative consumption (5.2 to $13.7 \%$ ) was similar to other regions of the Wadden Sea. Only 3 species (oystercatcher, curlew, common gull) consumed between 78 and $93 \%$ of the overall consumption of the 7 species examined. Whereas waders mainly foraged on the accompanying fauna of the $L$. conchilega community, the bulk of the diet of gulls was L. conchilega itself. In general, food supply on L. conchilega dominated flats can be judged as favourable. However, the possibility that food consumption could have been a limiting factor, at least for some species (e.g. oystercatcher), cannot be ruled out
\end{abstract}

KEY WORDS: Charadriiformes - Feeding ecology · Food consumption - Macrozoobenthos Phenology

\section{INTRODUCTION}

The Wadden Sea, comprising about $4500 \mathrm{~km}^{2}$ of intertidal flats, is the most important staging area for waders and waterfowl on the East Atlantic flyway. A total of 10 to 12 million birds of more than 50 species use the Wadden Sea as a stopover site during migra-

- Adressee for correspondence.

E-mail: exo@ifv-terramare.fh-wilhelmshaven.de tion or for wintering (Meltofte et al. 1994). However, there are only a few comparative studies which have examined spatial patterns of the preferred feeding sites of a whole waterbird community and thereby the importance of different flat types for different bird species and the impact of waterbirds on their prey populations (compilation in Baird et al. 1985, Meire 1993). This is particularly true for the Lower Saxonian part of the German Wadden Sea. There are no published studies evaluating the importance of different inter- 
tidal habitats of backbarrier tidal flats, although this is the most dominant flat type in the western Wadden Sea. Most studies have been restricted to a particular bird species or to Mytilus beds (Mytilus edulis L., 1758) (e.g. Hertzler 1995, Hilgerloh 1997), which cover only a small area of the intertidal flats (Herlyn 1996). Evaluation of the importance of different benthos communities as a potential food supply for waders and waterfowl is fundamental for understanding feeding ecology and therefore the adaptation of species to their annual habitats. It also enables us to predict the effects of habitat loss, e.g. due to large-scale constructions, fisheries, particularly musselfishery, tourism etc. (Meire 1993, Goss-Custard et al. 1994).

In the late 1980 s and early 1990s most benthos communities on backbarrier tidal flats of the Lower Saxonian Wadden Sea were dominated by Lanice conchilega (Pallas, 1766). For example, in the early 1990s more than $60 \%$ of the backbarrier tidal flats south of the island of Spiekeroog (see Fig. 1) were populated by $L$. conchilega, $30 \%$ of which were densely populated (Hertweck 1995); Arenicola marina (Linné, 1758) dominated $20 \%$ and Mytilus beds covered only about 5 to $10 \%$ of the tidal flats (cf. Hilgerloh 1997). Studies in English estuaries indicate that Lanice communities can be important as feeding sites for different wader species (Goss-Custard \& Jones 1976, Yates et al. 1993). The aim of our investigation was to estimate (1) the importance of 2 different $L$. conchilega dominated benthos communities for the most abundant migratory bird species and (2) the consumption by waterbirds on those flats. Additionally, this paper presents new data on food choice of the most abundant waterbirds. Thus, food supply and consumption of waterbirds was examined during autumn migration, that time of the year when consumption of birds on intertidal flats reaches a peak. Besides regular counts, detailed observations on 7 bird species were carried out: oystercatcher Haematopus ostralegus (L., 1758), curlew Numenius arquata (L., 1758), dunlin Calidris alpina (L., 1758), redshank Tringa totanus (L., 1758), common gull Larus canus L., 1758, black-headed gull Larus ridibundus L., 1766 and herring gull Larus argentatus Pontoppidon, 1763. These 7 species constituted more than $70 \%$ of all birds counted in the backbarrier tidal flats of Spiekeroog in autumn 1994.

\section{MATERIALS AND METHODS}

Study area and study period. The study area was located in the Lower Saxonian Wadden Sea on the backbarrier tidal flats south of the island of Spiekeroog (Fig. 1). Fieldwork covered the autumn migration period of the most abundant waterbirds, from the beginning of August to the end of October 1994. In order to survey the overall number of resting birds and their annual phenology, regular spring tide counts were carried out throughout the whole year of 1994 in the area between Neuharlingersiel and Harlesiel, as well as on the island of Spiekeroog (Fig. 1). Birds roosting on the island of Spiekeroog regularly fed on the Neuharlingersieler Nacken, as birds which roost on the mainland coast tend to do.
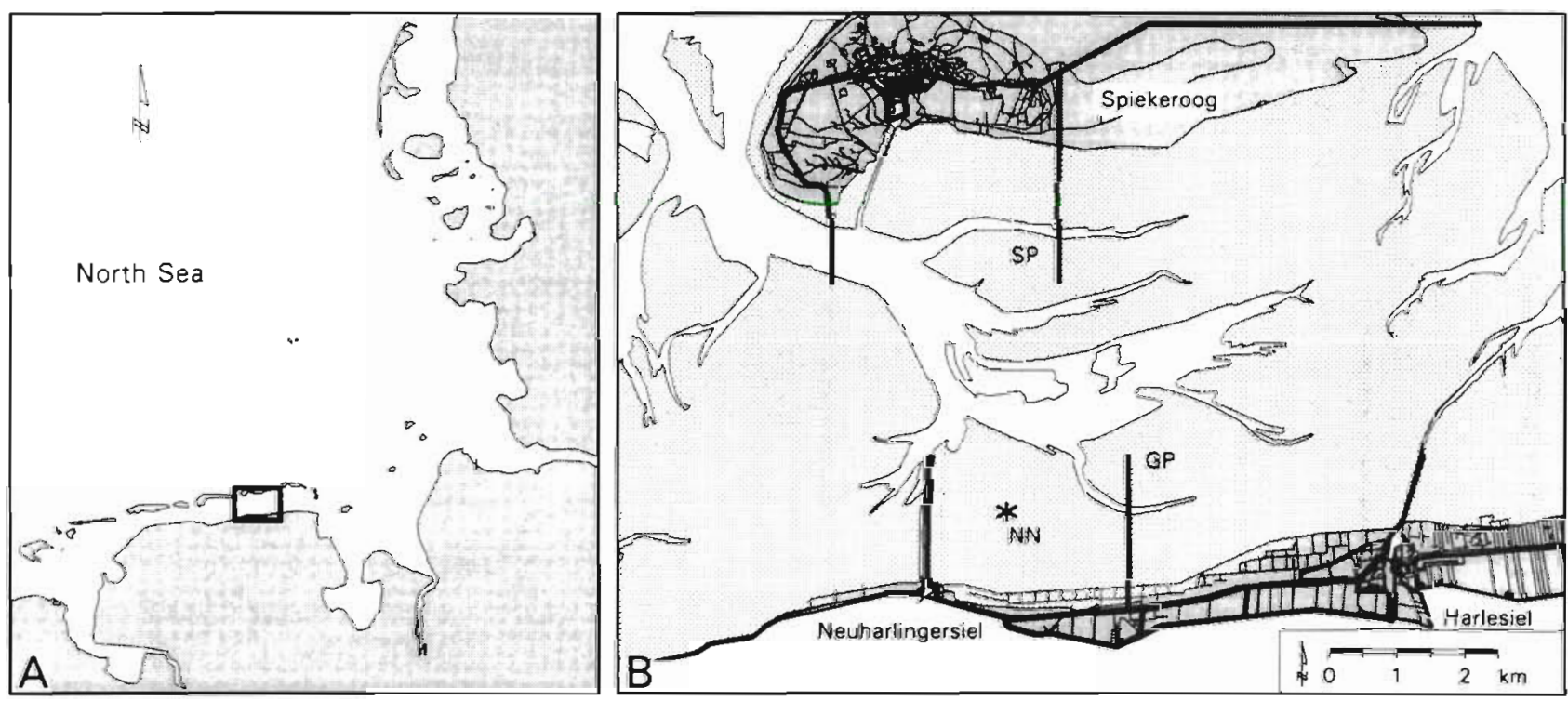

Fig. 1. (A) Location of the study area on (B) the backbarrier tidal flats of the island of Spiekeroog, Lower Saxonian Wadden Sea NN: Neuharlingersieler Nacken, GP: Gröninger Plate, SP: Swinnplate. * Position of the stationary observation tower and the study plots. Thick black lines indicate the boundaries of the 4 spring tide counting subareas 
The main study site was located on the Neuharlingersieler Nacken, about $1.5 \mathrm{~km}$ of the mainland coast (Fig. 1). The intertidal flats were dominated by Lanice conchilega and 2 types of flats were distinguished:

(1) 'Lanice flats' were of relatively flat and uniform area, about 0.75 to $1 \mathrm{~m}$ below mean high tide level with high $L$. Conchilega densities $\left(1630 \pm 850\right.$ ind. $\mathrm{m}^{-2}, \mathrm{n}=$ 15; see Fig. 3). At the end of August 1994, a spatfall of Mytilus edulis occurred (cf. Hilgerloh 1997).

(2) 'Undulating flats' were about $0.5 \mathrm{~m}$ below mean high tide level, with an undulating sediment surface structure (i.e. with slight hills). L. conchilega (1020 \pm 1060 ind. $\mathrm{m}^{-2}, \mathrm{n}=15$ ) and Mytilus edulis spat settled in lower densities and more patchily than on the Lanice flats.

Sediment composition was similar at both study sites, with sand $(>63 \mu \mathrm{m})$ proportions between 77.6 and $83.4 \%$ and corresponding silt proportions $(<63 \mu \mathrm{m})$ of 16.6 to $22.4 \%$. Therefore, both flat types could be categorized as mixed flats (Ssymank \& Dankers 1996).

Spring tide counts and estimation of theoretical bird densities. The total number of birds resting in the study area was surveyed by counts at high water during spring tides, i.e. about every 2 wk (for details see Rösner \& Prokosch 1992). The total area was divided into 4 subareas (Fig. 1). Counts were conducted from 2 to $3 \mathrm{~h}$ before until 2 to $3 \mathrm{~h}$ after high tide. Occasionally the 4 subareas could not be counted on the intended date due to inclement weather conditions or logistic problems. For analysis, counts from within $\pm 4 \mathrm{~d}$ of the intended dates were accepted. In total, 23 'simultaneous' spring tide counts were carried out in 1994 (1 count in February, 2 counts in each of the other months)

To calculate low tide bird densities from high tide counts we assumed a uniform distribution across the whole potential intertidal feeding area. Thus, expected (theoretical) bird densities were calculated by division of the numbers of birds counted at high tide by the intertidal flat area of 6680 ha. Regular observations of flight patterns during outgoing and incoming tide confirmed that there were no considerable movements into the study area from other roosting sites or out of the area to other feeding sites (cf. Schmidt 1998).

Low tide counts of birds. To estimate the utilization of Lanice conchilega dominated flats by waterbirds, bird density was studied on 5 plots of $50 \times 50 \mathrm{~m}$ on the Lanice flats and 3 on the Undulating flats. Observations were made from a stationary tower situated between the plots. The observer entered the tower during falling tide, before the first study plot emerged. All birds were counted every $20 \mathrm{~min}$ until all study plots were reflooded. When counting the birds, we differentiated between foraging and non-foraging birds. Counts were performed during 20 low tide periods in autumn 1994
( 7 counts each in August and October and 6 counts in September). Average emersion time of the plots was about $300 \mathrm{~min}$ per tidal cycle (range: 140 to $360 \mathrm{~min}$ ). Low tide counts of birds on defined plots have been used widely to estimate bird densities and thereby the utilization of distinct habitats (Zwarts \& Drent 1981, Engelmoer 1982, Nehls \& Tiedemann 1993, Meire 1993, Moreira 1994, 1995a,b, Scheiffarth \& Nehls 1998).

For the 7 most abundant bird species, average bird density per month and flat type was calculated from the numbers of foraging and non-foraging birds of each species on each plot in each counting interval. Then, the data were averaged over each of the 2 flat types across a whole tidal cycle. The number of feeding birds multiplied by the time interval of feeding (20 min) can be used as measures of foraging and predation intensity, respectively (e.g. Zwarts \& Drent 1981, Meire 1993). Therefore, for each month, bird hours per ha and tidal cycle were calculated.

Food abundance. Macrozoobenthos density was determined by sampling both flat types monthly. On both types of flats 5 samples were taken with a $10 \times 10 \mathrm{~cm}$ $\left(100 \mathrm{~cm}^{2}\right)$ corer, down to a depth of $30 \mathrm{~cm}$. Samples were sieved through a $1 \mathrm{~mm}$ mesh, sorted and fixed in Kohrsolin (instead of Formaldehyde, cf. Brey 1986; August: $50 \%$, September/October: 15 to 20\%). All organisms were counted and identified to species level. Furthermore, the length of potential prey species, such as mussels, Arenicola marina, Nereis divericolor, Nephthys hombergii and Carcinus maenas (width), was measured to the nearest mm. For further analyses, data from Nereis diversicolor O.F. Müller, 1776 and Nephthys hombergii Savigny, 1818 were combined as Nereis/Nephthys because differentiation was not possible when observing the prey species taken by feeding birds. Additionally, at each sampling station the number of lugworm casts (Arenicola marina) was counted on 5 plots of $50 \times 50 \mathrm{~cm}$ because this deep burrowing species was not sampled well by the small corer (e.g. Yates et al. 1993). Due to too-high concentrations of Kohrsolin (cf. Brey 1986), it was not possible to achieve appropriate biomass data by drying and burning. Thus, monthly ash free dry weight (AFDW) of the most important prey species [Mytilus edulis, Cerastoderma (Cardium) edule L., 1758, Ensis directus (Conrad), Nereis/Nephthys and Lanice conchilegal was estimated indirectly, from length-biomass ratios (Table 1).

Observations of foraging behaviour. Foraging behaviour was observed, whenever conditions such as light and distance to birds were favourable, to determine the prey species taken. Randomly selected individuals of the 7 most abundant bird species were observed by telescope (magnification: 20 to $60 \times$ ) for at least $1 \mathrm{~min}$, and normally not longer than $5 \mathrm{~min}$ ('focal animal sampling', Martin \& Bateson 1986). A total of 
665 observations, for a total of 2547 observation minutes, were used to determine prey taken, pecking and prey intake rates. In most cases prey size could also be identified. Three prey size classes were defined in relation to bill length or bill width for each bird species: 'small', $\leq$ half of bill length or $\leq$ double bill widthi 'middle', $1 / 2$ to 1 bill length or 2 - to 3 -fold bill width; 'large', $\geq$ bill length or $\geq 3$-fold bill width.

Data for bill length were taken from Cramp \& Simmons (1983), except data for redshank, for which our own measurements were used. Bill width data were measured from museum specimens.

Size classes of all polychaetes, Ensis directus and Crangon crangon were measured in relation to bill length, whereas size classes of Carcinus maenas, Macoma balthica L. and Cerastoderma edule were measured in relation to bill width of each species. For Mytilus edulis, it was necessary to differentiate among the bird species that took the prey. The 3 gull species are relatively short-billed; therefore, mussel length was estimated in relation to bill length. Oystercatcher and curlew are relatively long-billed; therefore, the width of the mussel was estimated in relation to the width of the bill. The regression of mussel length on mussel width of shells collected in the area enabled estimation of the $M$. edulis lengths taken by the latter 2 bird species: length $(\mathrm{mm})=1.6313$ width $(\mathrm{mm})+0.3599 ; \mathrm{r}^{2}=0.9056, n=31$. This was necessary since we calculated consumption of biomass with help of the biomass on length regressions for each prey species (Table 1).

Measuring size classes of prey in relation to bill length is a well-accepted method (Goss-Custard 1970, Burger et al. 1977, Pienkowski et al. 1984, Moreira 1994, 1995a). However, in order to test the accuracy of the estimation of size classes, it is necessary to calibrate the observations of each observer (Pienkowski et al. 1984, Goss-Custard et al. 1987. Cezilly \& Wallace 1988). For calibration, worm and shell models were held briefly to the bills of stuffed birds. The observer determined size classes of the models in the same way as in field studies. The field data were corrected by factors abtained through the calibration exercise (details in Petersen 1995). Based on these data (intake rate, prey species and prey size) prey and energy intake were calculated (cf. Table 3).

Food consumption. For the Lanice flat type, monthly species-specific food consumption was estimated as follows:

$$
C_{1}=\frac{1.97 \cdot e r_{1} I_{i} \cdot n_{m}}{c f}
$$

where $C_{i}=$ food consumption $\left(\mathrm{g} \mathrm{AFDW} \mathrm{m}^{-2}\right)$ of species $i$, $1.97=$ number of tidal cycles $\mathrm{d}^{-1}, e r_{i}=$ average monthly energy intake rate of species $i\left[\mathrm{~kJ} \mathrm{~min}^{-1}\right], I_{i}$ - foraging intensity in bird minutes of species $i\left[\mathrm{~min} \mathrm{~m}^{-2}\right], n_{m}=$ number of days of the month, and $c f=$ the conversion factor $\left(\mathrm{kJ}\right.$ in $\mathrm{g}$ AFDW) $21.5 \mathrm{~kJ} \mathrm{~g} \mathrm{AFDW}{ }^{-1}$.

There are many pitfalls when calculating the overall consumption of birds. Biomass and energy content of the prey species increase exponentially with length and width. Therefore, small mistakes in determining size classes can result in vast errors when calculating biomass or energy content. Also, at present we have to assume that waders feed at the same rate at nighttime and during daytime (review in McNeil et al. 1993). However, errors resulting from this assumption can be easily corrected later as data on nocturnal foraging become available. Using an average of $21.5 \mathrm{~kJ}$ g $\mathrm{AFDW}^{-1}$ for converting biomass values into energy contents should be an unimportant source of error.

\section{RESULTS}

\section{Total numbers and phenology of waterbirds}

In 1994 on the backbarrier tidal flats of the island of Spiekeroog a total of about 1250000 birds from 50 bird species were recorded, $41 \%$ (515000) of them during autumn migration, August to October 1994. Waders

Table 1. Relationship of biomass ( $y, g$ AFDW) to length $(x)$ of the most abundant prey species of the 7 bird species studied

\begin{tabular}{|c|c|c|c|}
\hline Species & & Length & Source \\
\hline Carcinus maenas & $y=\operatorname{Inv} \ln [2.871 \cdot \ln (x)-2.925] / 1.000$ & $\mathrm{~mm}$ & Zwarts \& Wanink (1993) \\
\hline Mytilus edulis & $y=\ln v \ln [2.84 \cdot \ln (x)-4.596] / 1000$ & $\mathrm{~mm}$ & Zwarts \& Wanink (1993) \\
\hline Cerastoderma edule & $y=\operatorname{Inv} \ln [3.099 \cdot \ln (x)-4.442] / 1000$ & mrn & Zwarts (1991) seasonal values for August to October \\
\hline Macoma balthica & $y=\operatorname{Inv} \ln [3.027 \cdot \ln (x)-4.657] / 1000$ & $\mathrm{~mm}$ & Zwarts (1991) seasonal values for August to October \\
\hline Ensis directus & $y=\operatorname{Inv} \ln [0.9561 \cdot \ln (x)+1.5764] / 1000$ & $\mathrm{~mm}$ & Calculated according to Swennen et al. (1985) \\
\hline Lanice conchilega & $y=\operatorname{Inv} \ln [1.3455 \cdot \ln (x)+0.8016] / 1000$ & $\mathrm{~cm}$ & Wahls (unpubl.) for July/August 1.994 \\
\hline Heteromastus filiformis & $y=\ln v \ln [1.0335 \cdot \ln (x)+0.2031] / 1000$ & $\mathrm{~cm}$ & Wahls (unpubl.) for July/August 1994 \\
\hline Arenicola marina & $y=\ln v \ln [2.2581 \cdot \ln (x)+0.1344] / 1000$ & $\mathrm{~cm}$ & Wahls (1995) \\
\hline Nereis diversicolor & $y=\operatorname{In} v \ln [1.5183 \cdot \ln (x)-2.7479] / 1000$ & $\operatorname{mm}$ & Wahls (1995) \\
\hline Crangon crangon & $y=\left(0.002305 \cdot x^{2.80657}\right) / 1000$ & $\mathrm{~mm}$ & Janssen (1980) in Kuipers \& Dapper (1981) \\
\hline
\end{tabular}




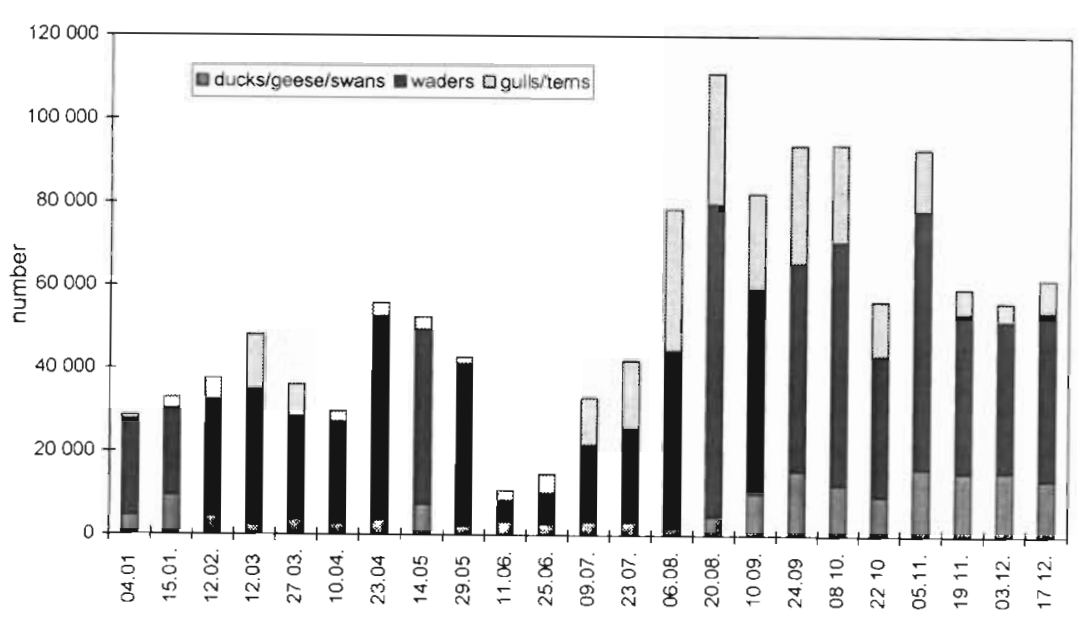

Fig. 2. Phenology of waterbirds resting on the backbarrier tidal flats of Spiekeroog 1994. Total number per counting date (day.month.) in 1994 between 3360 and $5520 \mathrm{~m}^{-2}$ on the Undulating flat, and between 8520 and $1100 \mathrm{~m}^{-2}$ on the Lanice flat. Correspondingly, the estimated biomass ranged from 67.6 to $142.3 \mathrm{~g} \mathrm{AFDW} \mathrm{m}^{-2}$ and 128.4 to $337.2 \mathrm{~g} \mathrm{AFDW} \mathrm{m}^{-2}$, respectively. The most abundant species were Heteromastus filiformis (Claparède, 1864), L. conchilega, Macoma balthica and Mytilus edulis (Fig. 3), each of which was recorded at a density of more than $1000 \mathrm{~m}^{-2}$ in at least 1 of the 3 mo. Further potentially important prey organisms present at densities of at least $>100 \mathrm{~m}^{-2}$ in $1 \mathrm{mo}$, were Nereis/Nephthys, Carcinus maenas, were the dominant group (about $60 \%$ ), followed by gulls/terns (30\%) and ducks/ geese (10\%; Fig. 2). Smallest numbers were present in June (ca 11000 ), the main breeding period, and the maximum count of about 111000 birds was made at the end of August. During spring migration, a maximum of about 56000 birds were present. The winter minimum occurred in January (29000 birds).

During autumn migration, the most abundant waterbirds in the whole backbarrier tidal area (more than 10000 of each) were dunlin, oystercatcher, herring gull, curlew, black-headed gull, grey plover and common gull. Most waders roosted almost exclusively $(>95 \%)$ on the island of Spiekeroog: dunlins, grey plovers, whimbrels $\mathrm{Nu}$ menius phaeopus and Bar-tailed Godwits Limosa lapponica, as well as Brent goose (Tadorna tadornal and lesser black-backed gulls Larus fuscus and 85 to $90 \%$ of oystercatchers and curlews. Amongst the 3 most abundant gull species, only herring gulls showed a pronounced preference for resting on the island $(82 \%)$, whereas about $55 \%$ of the black-headed and common gulls were found on the mainland coast.

\section{Macrozoobenthic food supply}

In autumn 1994, a total of 21 macrozoobenthos species or species groups were found. The overall numbers varied

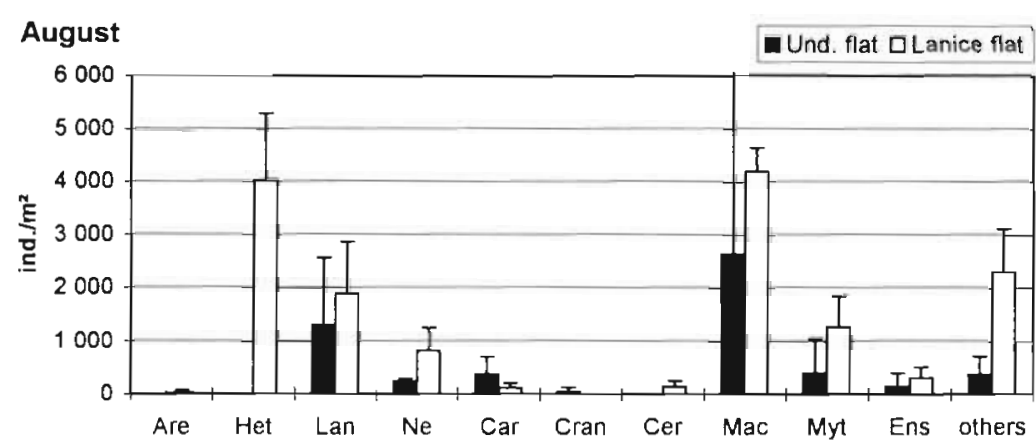

September

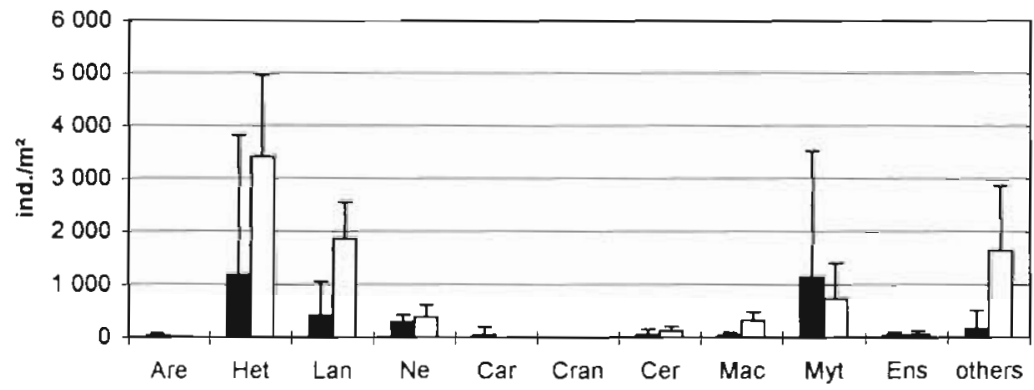

\section{October}

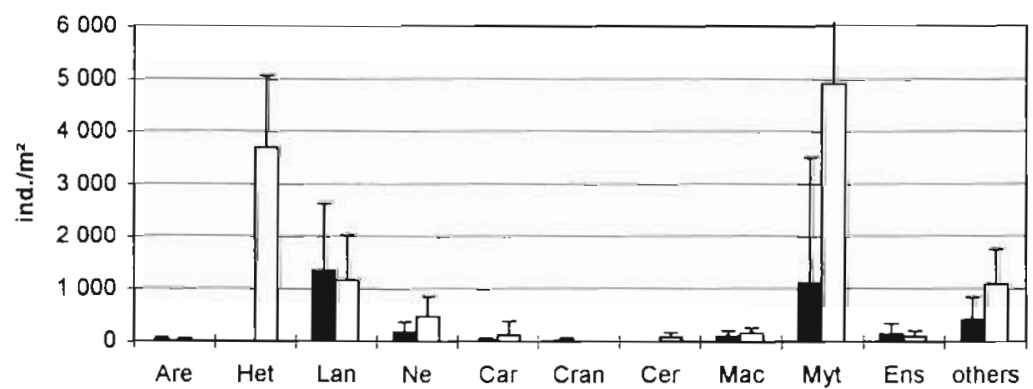

Fig. 3. Mean (+SD) population densities of the most abundant macrozoobenthos species on the 2 investigated flat types in autumn 1994 (Und. flat: Undulating flat). Are $=$ Arenicola marina, Het $=$ Heteromastus filiformis, Lan $=$ Lanice conchilega, $\mathrm{Ne}=$ Nereis $/$ Nephthys, $\mathrm{Car}=$ Carcinus maenas, Cran = Crangon crangon, Cer = Cerastoderma edule, $\mathrm{Mac}=$ Macoma balthica, $\mathrm{Myt}=$ Mytilus edulis, Ens = Ensis directus 
Cerastoderma edule and Ensis directus. Despite high variations between sampling stations, characteristic differences existed in space and time (Fig. 3):

Lanice conchilega was found at higher densities (up to a mean of about $2000 \mathrm{~m}^{-2}$ ) on the Lanice flat than on the Undulating flat (about $1300 \mathrm{~m}^{-2}$ ) in August and September (Kruskal-Wallis-Test: $\mathrm{p}<0.05$ ). Heteromastus filiformis occurred almost exclusively and at high densities (up to ca $4000 \mathrm{~m}^{-2}$ ) on the Lanice flat ( $\mathrm{p}<$ 0001 ). Arenicola marina density during all months was higher on the Undulating flat than on the Lanice flat, 14 to $30 \mathrm{~m}^{-2}$ and 6 to $18 \mathrm{~m}^{-2}$, respectively, but the difference was not significant. Macoma balthica occurred in high densities only in August, as spat (Lanice flat: ca $4000 \mathrm{~m}^{-2}$, Undulating flat: ca $2500 \mathrm{~m}^{-2}$; difference not significant). In September and October, densities decreased on both tidal flat types to below $500 \mathrm{~m}^{-2}$. Over the whole period, densities were higher on the Lanice flat $(p<0.05)$. Mytilus edulis samples revealed a spatfall from the end of August onwards, particularly on the Lanice flat $(\mathrm{p}<0.05)$, but the sampling method did not properly record the patchy distribution. Mussel lengths varied between 5 and $27 \mathrm{~mm}(16.6 \pm 10.3 \mathrm{~mm}$, $\mathrm{n}=491$; cf. Hilgerloh 1997).

In total, the Lanice flat contained higher numbers of all dominant prey species than the Undulating flat.

\section{Bird densities}

In 3 of the 7 bird species studied in detail - common gull, herring gull and oystercatcher-foraging densities differed significantly between the 2 types of tidal flats (Kruskal-Wallis-Test: $\mathrm{p}<0.05$ ). In general common gulls and herring gulls preferred the Undulating flat type, whereas oystercatchers showed a preference for one of the Lanice flat plots (Table 2). However, significant differences in bird densities never occurred within one type of flat, but only between plots of different type.
Oystercatcher: While the overall number present in the whole study area, and thereby the expected low tide density, was relatively constant from August to October (2.1 to 2.2 birds ha $^{-1}$, Table 2 ), the average observed bird densities on the study plots increased from 4.2 birds ha $\mathrm{a}^{-1}$ in August to $15.3 \mathrm{birds} \mathrm{ha}^{-1}$ in October on the Undulating flat and from 8.7 to 19.3 birds $\mathrm{ha}^{-1}$ on the Lanice flat. Therefore, oystercatcher densities on the Lanice flats in August were about 2 to 4 times higher than expected assuming a uniform distribution across the whole intertidal area and 6 to 9 times higher in September and October. During all 3 mo of investigation, oystercatchers preferred the Lanice flat.

Dunlin: Overall dunlin numbers remained fairly constant over the autumn migration period (2.3 birds ha- ${ }^{-1}$, Table 2). In August, dunlins preferred the Undulating flat (5.2 birds $\mathrm{ha}^{-1}$ ), whereas the observed density on the Lanice flat ( 2.7 birds $h^{-1}$ ) was of the same order of magnitude as the expected density. However, in September dunlins preferred the Lanice flat and avoided the Undulating flat. In October, both tidal flats held very few dunlins.

Curlew: The migration period of the curlew begins in late June/early July. Average expected bird densities decreased from August/September to October (Table 2). On both tidal flat types, observed bird densities were at least 2 to 3 times the expected values over the whole period of investigation. In August and September, curlews preferred the Lanice flat, in September density was nearly 5 -fold the expected low tide density. In October, most of the remaining curlews were found on the Undulating flat.

Redshank: Numbers for redshanks were comparatively low, up to about 1100 birds. However, they used both flat types during the whole migration period in higher densities than expected (Table 2).

Black-headed gull: During autumn 1994, the number of black-headed gulls decreased strongly from August/September to October (Table 2). In August and October, both flat types were used by black-headed

Table 2. Comparison of 'expected bird densities' (ED) - as calculated from spring tide counts - with 'observed bird densities' (OD) on 2 different types of Lanice conchilega dominated flats (Und. flat: Undulating flat). Values show mean number of birds $\mathrm{ha}^{-1} \pm \mathrm{SD}$ (August and October: $84 \mathrm{~h}$ of observation; September: $72 \mathrm{~h}$ )

\begin{tabular}{|c|c|c|c|c|c|c|c|c|c|}
\hline \multirow[t]{2}{*}{ Bird species } & \multirow[t]{2}{*}{ ED } & \multicolumn{2}{|c|}{ August } & \multirow{2}{*}{ ED } & \multicolumn{2}{|c|}{$\begin{array}{c}\text { September } \\
\text { Observed density }\end{array}$} & \multirow[t]{2}{*}{$\mathrm{ED}$} & \multicolumn{2}{|c|}{ October } \\
\hline & & Und. flat & Lanice flat & & Und flat & Lanice flat & & Und. flat & Lanice flat \\
\hline Haematopus ostralegus & 2.2 & $4.2 \pm 6.4$ & $8.7 \pm 13.9$ & 2.1 & $12.1 \neq 21.9$ & $12.6 \pm 21.9$ & 2.1 & $15.3 \pm 20.1$ & $19.3 \pm 27.6$ \\
\hline Calidris alpina & 2.3 & $5.2 \pm 11.6$ & $2.7 \pm 8.5$ & 2.3 & $0.8 \pm 1.8$ & $3.9 \pm 13.6$ & 2.3 & $0.2 \pm 0.5$ & $0.5 \pm 0.9$ \\
\hline Numenius arquata & 1.5 & $4.4 \pm 7.9$ & $5.5 \pm 12.4$ & 1.7 & $3.6 \pm 5.7$ & $7.9 \pm 1.3 .7$ & 1.1 & $4.1 \pm 5.8$ & $2.7 \pm 3.8$ \\
\hline Tringa totanus & 0.2 & $0.5 \pm 1.2$ & $0.8 \pm 2.3$ & 0.2 & $0.3 \pm 0.7$ & $1.1 \pm 3.0$ & 0.1 & $0.6 \pm 1.4$ & $0.3 \pm 0.8$ \\
\hline Larus ridibundus & 1.8 & $4.0 \pm 7.3$ & $8.3 \pm 14.1$ & 1.5 & $1.5 \pm 2.8$ & $1.3 \pm 2.2$ & 0.7 & $2.4 \pm 4.8$ & $0.2 \pm 0.6$ \\
\hline Larus argentatus & 1.9 & $0.7 \pm 1.8$ & $0.2 \pm 0.4$ & 1.6 & $0.8 \pm 2.2$ & $0.7 \pm 3.6$ & 1.8 & $6.2 \pm 15.4$ & $2.8 \pm 7.7$ \\
\hline Larus canus & 0.6 & $25.0 \pm 32.6$ & $15.2 \pm 23.6$ & 0.4 & $39.1 \pm 50.9$ & $14.2 \pm 20.9$ & 0.2 & $10.3 \pm 17.0$ & $5.6 \pm 10.6$ \\
\hline
\end{tabular}


gulls in higher densities than expected. In August they preferred the Lanice flat, in October the Undulating flat. Therefore, there was no clear preference for a flat type.

Herring gull: The number of herring gulls remained relatively constant (Table 2). Whereas observed bird density was much lower than expected in August and September on both flat types, in October the observed density was higher than the expected density.

Common gull: Numbers of common gulls decreased steadily from August to October (Table 2). On both flat types, observed bird densities far exceeded expected values during the whole period of autumn migration. In October, the observed density was about 100 times that expected on the Undulating flat. Over the 3 mo period, common gulls showed a constant preference for the Undulating flat.

\section{Food and food consumption}

Depending on the bird species, between $6.5 \%$ and $47 \%$ of prey organisms taken could not be identified (Fig. 4). However, due to the high number of observation samples, the most important prey species are known. As the unidentified prey species were mostly very small, their contribution to total biomass intake may be low (e.g. Wahls 1995) and therefore ignored.

Oystercatchers fed almost exclusively on bivalves (ca $80 \%$ ), chiefly Mytilus edulis (nearly $40 \%$ ), Cerastoderma edule (14\%) and Ensis directus (10\%) (Fig. 4). For curlews, Carcinus maenas was the most important prey species, almost $50 \%$ of the diets; polychaetes formed about $25 \%$. Redshanks fed mostly on Carcinus maenas and Crangon crangon (each up to $25 \%$ ). The diet of the dunlin included about $16 \%$ of these 2 crustaceans, but a further $33 \%$ comprised various polychaetes. Thus waders foraging on Lanice conchilega dominated flats fed mainly on the accompanying fauna of the L. conchilega community and hardly on $L$. conchilega itself.

In contrast to the diet of waders, the bulk of the diet of at least 2 of the 3 observed gull species was made up of Lanice conchilega, i.e. $63 \%$ of the diet of the blackheaded gull, $59 \%$ for the common gull and $42 \%$ for the herring gull (Fig. 4). The herring gull, which is known for its opportunistic foraging behaviour (e.g. Glutz von Blotzheim \& Bauer 1982), fed on only 2 main prey species: Mytilus edulis (50\%) and L. Conchilega itself $(42 \%)$.

The overall consumption of the 7 bird species studied decreased on the Lanice flat from $16.6 \mathrm{~g} \mathrm{AFDW} \mathrm{m}^{-2}$ in August to $12.3 \mathrm{~g} \mathrm{AFDW} \mathrm{m}^{-2}$ in October (Table 3). Only 3 species (oystercatcher, curlew and common gull) were responsible for almost $78 \%$ (August), 93\%
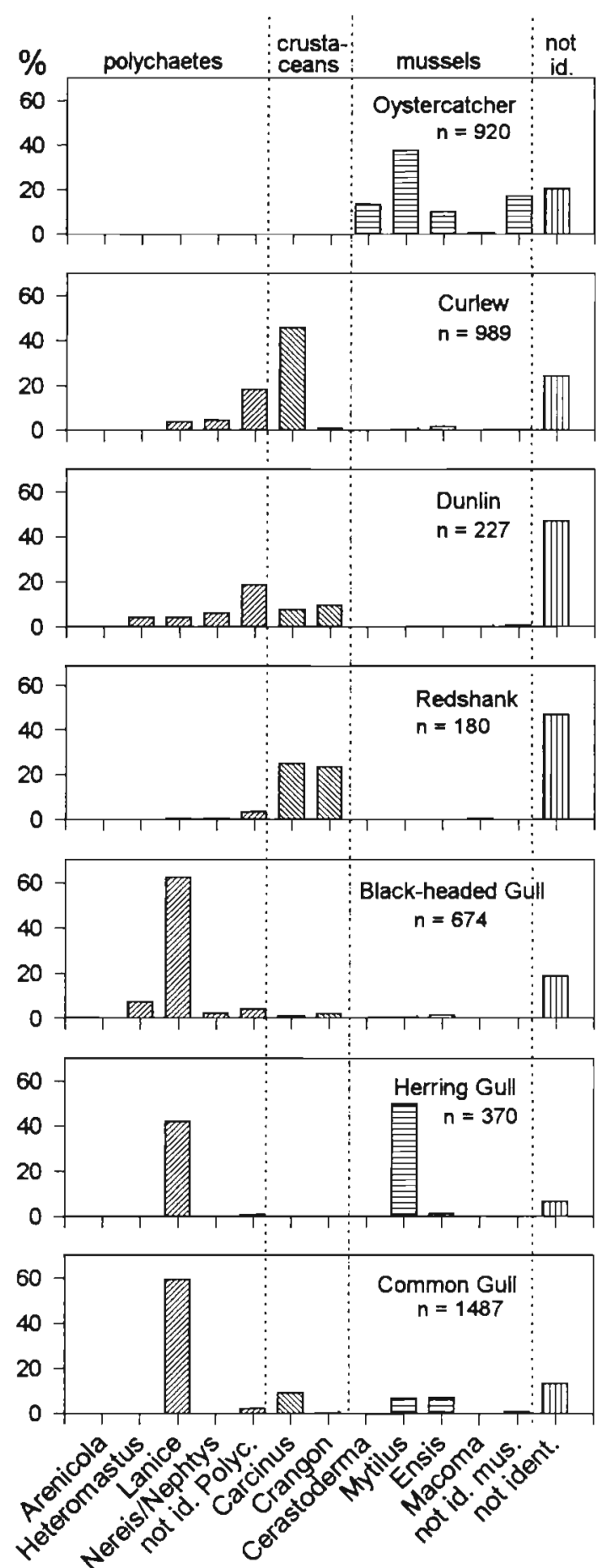

Fig. 4. Diet composition of the 7 examined bird species. $\mathrm{n}=$ total number of observed prey organisms. not id.: not identified; not id. mus.: unidentified mussels; not id. Poliyc.: not identified Polychaetes. See Fig. 3 legend for species names

(September) and $81 \%$ (October) of the overall consumption of the 7 species. The 7 bird species consumed almost $10 \%$ in August and September and only $4 \%$ in October of the total biomass present on the study plots (Tables $3 \& 4$ ). 
Table 3. Monthly consumption of the 7 bird species examined and their overall consumption [ $g$ AFDW $\mathrm{m}^{-2}$ ] on the Lanice flat. See Table 2 for genus names

\begin{tabular}{|lcccccccc}
\hline 1994 & H. ostralegus & N. arquata & C.alpina & T totanus & L. canus & L. ridibundus & L. argentatus & Total \\
\hline August & 3.81 & 2.25 & 0.23 & 0.12 & 6.86 & 3.31 & 16.58 \\
September & 4.63 & 2.97 & 0.56 & 0.13 & 4.99 & 0.33 & 13.57 \\
October & 5.36 & 1.03 & 0.06 & 0.06 & 3.61 & 0.11 & 2.08 \\
\hline
\end{tabular}

Table 4. Mean food supply (main prey species) in relation to the overall mean consumption of the 7 bird species on the Lanice flat from August to October 1994. Percent biomass consumed shown in parentheses

\begin{tabular}{|c|c|c|c|c|c|c|c|}
\hline & $\begin{array}{c}\text { Lanice } \\
\text { conchilega }\end{array}$ & $\begin{array}{l}\text { Nereis/ } \\
\text { Nephthys }\end{array}$ & $\begin{array}{l}\text { Mytilus } \\
\text { edulis }\end{array}$ & $\begin{array}{c}\text { Ensis } \\
\text { directus }\end{array}$ & $\begin{array}{c}\text { Cerastoderma } \\
\text { edule }\end{array}$ & $\begin{array}{c}\text { Biomass } \\
\text { (g AFDW m }{ }^{-2} \text { ) }\end{array}$ & 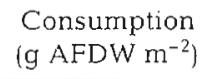 \\
\hline \multicolumn{8}{|l|}{ August } \\
\hline Length $(\mathrm{mm})$ & 70 & 55 & 13 & 38 & 23 & & \\
\hline g AFDW ind ${ }^{-1}$ & 0.03 & 0.028 & 0.015 & 0.157 & 0.195 & & \\
\hline Biomass $\mathrm{m}^{-2}$ & 56.4 & 22.96 & 18.9 & 47.1 & 27.3 & 172.7 & $16.6(9.6 \%)$ \\
\hline \multicolumn{8}{|l|}{ September } \\
\hline Length (mm) & 65 & 57 & 18 & 47 & 24 & & \\
\hline $\mathrm{g}$ AFDW ind ${ }^{-1}$ & 0.028 & 0.03 & 0.037 & 0.192 & 0.223 & & \\
\hline Biomass $\mathrm{m}^{-2}$ & 52.08 & 11.4 & 26.64 & 11.52 & 26.76 & 128.4 & $13.6(10.6 \%)$ \\
\hline \multicolumn{8}{|l|}{ October } \\
\hline Length (mm) & 65 & 30 & 19 & 48 & 37 & & \\
\hline g AFDW ind. ${ }^{-1}$ & 0.028 & 0.011 & 0.043 & 0.196 & 0.853 & & \\
\hline Biomass $m^{-2}$ & 32.48 & 5.28 & 211.56 & 19.6 & 68.24 & 337.2 & $12.3(3.7 \%)$ \\
\hline
\end{tabular}

\section{DISCUSSION}

\section{Bird numbers and distribution}

The backbarrier tidal flats of the island of Spiekeroog hosted more than 20000 waterbirds over most of 1994 and in other years too (Fig. 2 i unpubl. data). Thereby the area fulfils criterion 3(a) of the Rasmar Convention for wetlands of international importance (e.g. Mitlacher 1997). The spatial distribution of the birds depends on a variety of biotic and abiotic factors. The existence of suitable resting and feeding areas are main factors determining the distribution on a larger scale. For energetic reasons, resting and feeding areas are expected to be fairly close together (e.g. Goss-Custard 1977). During autumn migration 1994, most waders rested on the island of Spiekeroog, particularly the eastern part of the island, where resting sites, mainly saltmarshes, are larger and less disturbed than those along the mainland coast. PubIic access to the saltmarshes is prohibited, and the eastern parts of the islands are protected strongly ('Zone I') as part of the 'National Park Lower Saxonian Wadden Sea'. The saltmarshes on the mainland in front of the dikes are protected too, but they are fairly small and therefore much more disturbed-e.g. by tourists-despite protection. Additionally, when water levels are high, e.g. during spring tides or strong western winds, these small saltmarshes are flooded and no longer offer suitable roosting sites.

On the other hand, most of the tidal flats close to the mainland coast are more muddy than those adjacent to the islands (Flemming \& Ziegler 1995). Therefore, they may support higher densities of potential prey species. This may explain, at least to some extent, why many of the birds regularly fly distances of up to 5 to $10 \mathrm{~km}$, up to 4 times a day, between their resting and feeding sites. Many waders resting on Spiekeroog, e.g. oystercatcher, curlew, grey plover and dunlin, flew to emerging mudflats close to the mainland coast, including the flats studied. They fed there during low tide and then flew back to their resting sites on the island with the rising tide. Comparable results were obtained in cther areas of the East Frisian Wadden Sea (Wahls 1995, Schmidt 1998, Ketzenberg \& Exo unpubl.). Therefore, the backbarrier tidal flats, including the islands, have to be considered as an ecological unit, especially for migratory waterbirds.

\section{Macrozoobenthos}

The species composition of the macrozoobenthos communities examined on the Neuharlingersieler Nacken is known as a 'Wadden Sea variant' of the Macoma balth- 
ica community (Michaelis \& Böhme unpubl.). The number of species found in this study (21) was of the same order of magnitude as the numbers of species found in previous studies in the region (Grotjahn 1990, Kröncke 1995, 1996 in Flemming 1995, Niemeyer \& Michaelis unpubl.). However, in autumn 1994, the overall numbers (averages of 4100 and $11800 \mathrm{~m}^{-2}$ on the Undulating flats and the Lanice flats, respectively) were at the lower end of the range examined by Grotjahn (1990) in the mid 1980 s ( 7500 to $144000 \mathrm{~m}^{-2}$ ), but much higher than on the nearby Gröninger Plate (Fig. 1) in 1994 (March to August 1994: 648 to $2100 \mathrm{~m}^{-2}$; Bernem et al. unpubl., Michaelis \& Niemeyer unpubl.). Correspondingly, the biomass on the Gröninger Plate (mean: $18.1 \mathrm{~g} \mathrm{AFDW} \mathrm{m}^{-2}$, range: 5.2 to $49.4 \mathrm{~g}$ AFDW $\mathrm{m}^{-2}$ in spring 1994, Michaelis \& Niemeyer 1995) was much lower than on the flats of the Neuharlingersieler Nacken (range: 68 to $337 \mathrm{~g}$ AFDW $\mathrm{m}^{-2}$ ). Because of their high biomass and productivity, blue mussel beds are often important feeding sites for coastal birds. However, in spring 1994, biomass of mussel beds in the backbarrier tidal flats of Spiekeroog was rather low. For mature mussel beds, Hilgerloh (1997) estimated about $21 \mathrm{~g} \mathrm{AFDW} \mathrm{m}^{-2}$ (only for Mytilus) and for young mussel beds $328 \mathrm{~g} \mathrm{AFDW} \mathrm{m}^{-2}$. Biomass of the Lanice conchilega dominated flats was of the same order of magnitude.

In autumn 1994 abundances and biomass of zoobenthos on the Neuharlingersieler Nacken were higher than in most other Wadden Sea areas, too (e.g. Beukema 1981, Piersma et al. 1993, Reise \& Lakschewitz 1998; Table 5). However, the most important fac- tor determining the quality of a feeding site is prey availability (Evans 1976, 1987, Pienkowski 1983, Evans \& Dugan 1984, Zwarts \& Wanink 1991, 1993). Vertical distribution and surface activity, which determine detectability, and therefore availability of invertebrates to birds, are dependent on a variety of biotic and abiotic factors, such as temperature and wetness (Burger 1984, Zwarts \& Wanink 1993). Due to the structure of the flats studied, especially of the Undulating flats, at least parts of the plots were covered by water during the whole tidal cycle, even during low tide. Only at the beginning of October, was temperature below a 'critical' value of $6^{\circ} \mathrm{C}$ for the activity of benthos (Zwarts \& Wanink 1993). Up until then, the conditions seemed to be good for high availability of potential prey species.

\section{Food supply and consumption}

In accordance with the good food supply on both flat types, numbers of foraging birds were comparatively high (Table 2). The highest overall density of the 7 bird species reached an average of 50 birds ha ${ }^{-1}$ (Lanice flat), 6 times higher than expected assuming a uniform distribution of the birds over the whole intertidal area. These values apply to 7 species which correspond to only $70 \%$ of all birds present in the area. Therefore, total bird densities were probably even higher. Though bird density and therefore food consumption may be influenced by the structure of the area, the emersion

Table 5. Consumption of waterbirds in different regions of the Wadden Sea in comparison to the standing stock of macrozoobenthos. Values for the Neuharlingersieler Nacken (Neuh. Nack.) show overall consumption for the 7 examined bird species and the estimation on all birds present in the area. Values given in the literature are theoretical estimations on the basis of high tide counts and energetical needs of the birds

\begin{tabular}{|c|c|c|c|c|c|c|c|c|}
\hline & $\begin{array}{r}\text { Consı } \\
\text { (g AFI } \\
7 \text { birds }\end{array}$ & $\begin{array}{l}\text { imption } \\
\text { All birds }\end{array}$ & $\begin{array}{c}\text { Autumn } \\
\text { prey biomass } \\
\left.\text { (g AFDW m } \text { A }^{-2}\right)\end{array}$ & $\begin{array}{l}\% \text { Cons } \\
\text { Autumn p } \\
7 \text { birds }\end{array}$ & $\begin{array}{l}\text { sumption } \\
\text { rey biomass } \\
\text { All birds }\end{array}$ & $\begin{array}{c}\text { Avg. prey } \\
\text { biomass } \\
\text { (g AFDW m } \text { (g) }^{-2} \text { ) }\end{array}$ & $\begin{array}{c}\% \text { Consumption } \\
\text { Avg. prey } \\
\text { biomass }\end{array}$ & Source \\
\hline \multicolumn{9}{|l|}{ Neuh. Nack. } \\
\hline August & 16.6 & 23.7 & 172.7 & 9.6 & 13.7 & & & \multirow[t]{3}{*}{ This study } \\
\hline September & 13.6 & 19.4 & 128.4 & 10.6 & 15.1 & & & \\
\hline October & 12.3 & 17.6 & 337.2 & 3.7 & 5.2 & & & \\
\hline \multicolumn{9}{|l|}{ Oosterschelde } \\
\hline 1985 & & 11.5 & 49.3 & & 23.3 & & & \multirow[t]{2}{*}{ Meire et al. (1993) } \\
\hline 1986 & & 13.2 & 99.3 & & 13.3 & & & \\
\hline \multicolumn{2}{|l|}{ Westerschelde } & 4.1 & 15.1 & & 27.2 & & & Meire et al. $(1989)^{\mathrm{a}}$ \\
\hline \multicolumn{2}{|l|}{ Grevelingen } & 8.2 & & & & 72 & 11.4 & Wolff et al. $(1976)^{d}$ \\
\hline \multicolumn{2}{|l|}{ Wadden Sea } & 4.7 & & & & 26.6 & 17.6 & Smit $(1980)$ \\
\hline \multirow{2}{*}{\multicolumn{2}{|c|}{$\begin{array}{l}\text { Sylt-Romø (eulittoral) } \\
\text { Königshafen at Sylt } \\
\text { (eulittoral) }\end{array}$}} & 8.7 & & & & 50 & 17.4 & \multirow{2}{*}{$\begin{array}{l}\text { Scheiffahrt \& } \\
\text { Nehls (1997) }\end{array}$} \\
\hline & & 17.6 & & & & 65 & 27.1 & \\
\hline \multicolumn{6}{|c|}{${ }^{a}$ from Meire et al. (1993) } & & & \\
\hline
\end{tabular}


time, the distance to the high tide roosting sites etc., the main factor determining the bird density on $L$. conchilega dominated flats seemed to be the comparatively good food supply. Energy intake gives a further indication of the good food supply for at least some bird species. During $6 \mathrm{~h}$ of emersion time, 5 out of the 7 bird species examined (all 3 gull species, redshank and curlew) were able to collect more food than necessary to cover their daily energy demands (Petersen 1995).

Of the 7 bird species studied, 4 (common gull, oystercatcher, curlew and redshank), used both types of flats in higher densities than expected (Table 2). The preference for Lanice flats of oystercatchers was probably due to the occurrence of Mytilus edulis on that type of flat (cf. Fig. 4). Whereas in August and September curlews and redshanks showed a preference for the Lanice flat too, in October, both preferred the Undulating flat. Curlews and redshanks fed mainly on crustaceans (Fig, 4). The change in preference was probably caused by a greater availability of crustaceans on this more structured flat type late in autumn (cf. Hertzler 1995), and not directly by the abundance of L. conchilega itself (cf. Yates et al. 1993). Comparable seasonal changes in the preferences of different benthos communities have recently been published by Tiedemann \& Nehls (1997).

During autumn migration 1994, monthly overall consumption of the 7 bird species studied varied between 12.3 and $16.6 \mathrm{~g} \mathrm{AFDW} \mathrm{m}^{-2}$ (Tables $3 \& 4$ ). Assuming a corresponding consumption rate for the remaining $30 \%$ of birds, the overall consumption of all birds would have varied between 17.6 and $23.7 \mathrm{~g}$ AFDW $\mathrm{m}^{-2}$. Compared with other regions of the Wadden Sea, these values are high (Table 5). Food densities were high too, therefore the relative consumption, 5.2 to $13.7 \%$ of the biomass of the standing stock, was similar to other regions of the Wadden Sea. On average, birds consume between 10 and $40 \%$ of the macrozoobenthos biomass throughout the year (Smit 1980, Goss-Custard 1984, Meire 1993, Scheiffarth \& Nehls 1997). Higher consumption rates usually appear only on a local scale or apply only to distinct prey species or distinct size classes of certain prey species. However, only a small fraction of the overall biomass is available and profitable for birds (e.g. Pienkowski 1983, Beukema et al. 1993, Meire 1993, Zwarts \& Wanink 1993). Assuming only $25 \%$ of the biomass was available (cf. Smit 1980), the 7 species consumed $38 \%$ of the available biomass in August, $42 \%$ in September, and only 15\% in October

Although on Lanice conchilega dominated flats food supply in general can be judged as favourable, the possibility that food could have been a limiting factor, at least for a few species, cannot be ruled out. Though the observed density of oystercatchers, an average of
10 to 20 birds ha ${ }^{-1}$ (per tidal cycle), was much higher than the expected density (Table 2), abundance was low in comparison to other regions and flat types. For example, on mussel beds in the Delta region of the Netherlands, or on Schiermonnikoog, densities of about 50 birds ha ${ }^{-1}$ and up to more than 100 birds ha $^{-1}$ were recorded (Zwarts \& Drent 1981, Meire 1991, 1993). That food supply for oystercatchers was not very favourable in autumn 1994 is demonstrated by the fact that they consumed a high proportion of small mussels, mainly less than $20 \mathrm{~mm}$ (cf. Zwarts et al. 1996). Therefore, energy intake of oystercatchers was low, about 0.5 to $1.6 \mathrm{~kJ} \mathrm{~min}{ }^{-1}$. According to Zwarts et al. (1996), mean intake in summer is about $2.8 \mathrm{~kJ} \mathrm{~min}^{-1}$. It may be that less efficient subdominant oystercatchers fed in the area. Mussel beds have decreased tremendously in the Lower Saxonian Wadden Sea during the last decades and cover only small areas on the tidal flats south of Spiekeroog (Michaelis et al. 1995, Herlyn 1996. Hilgerloh 1997). On the other hand, oystercatcher numbers have increased in the East Frisian Wadden Sea (Zang et al. 1995).

Our investigations give evidence that mixed flats dominated by Lanice conchilega, were of overall importance as foraging areas for large numbers of migratory birds. L. conchilega was of overriding importance for a few species, especially for gulls, while for others, mainly waders, the accompanying macrozoobenthos species were more significant (cf. GossCustard \& Jones 1976, Yates et al. 1993). Especially in intertidal areas, many biotic and abiotic factors may vary dramatically in space and time. Therefore, the results presented here can only be interpreted as an initial indication of the relevance for migratory waterbirds of mixed flats dominated by $L$. conchilega. For comprehensive analyses of the importance of different benthos communities in backbarrier tidal flats, longterm investigations covering both (1) spring and autumn migration as well as winter and (2) the most important benthos communities are required.

Acknowledgements. B P thanks Prof. Dr H. Plachter ('Institute of Biology/Department of Nature Conservation', PhilippsUniversität-Marburg) for making this diploma thesis possible and the Institut für Vogelforschung 'Vogelwarte Helgoland', Wilheimshaven, for working space, material and very good guidance. The extensive fieldwork would not have been possible without the help of U. Bradter, K. Hagen, C. Ketzenberg, J. Milde, N. Lindner and J. Scharlemann. J Reichel and R. Zühike gave helpful advice for sampling the benthos. The Forschungsinstitut Senckenberg, Wilhelmshaven, provided assistance with the analysis of sediment samples, the Forschungszentrum Terramare e.V., Wilhelmshaven, and the Meeresbiologische Station/University of Münster, Carolinensiel, provided further logistical assistance. Members of the 'Wissenschaftliche Arbeitsgemeinschaft für Natur- und Umweltschutz e.V., Jever (WAU)' and the 'Staatliches Amt für 
Insel- und Küstenschutz, Norden (StAIK)' counted the birds. F. Bairlein, P. H. Becker, H. Höker, R. Dröschmeister, Barbara Pohl, Suse Kratzer and an anonymous referee improved earlier drafts. Many thanks to all of them! This work was supported financially by the Bundesministerium für Bildung, Wissenschaft, Forschung und Technologie (BMBF) under the grant 03F0112A. Responsibility for the contents of this publication rests with the authors. This is publication no. 243 of the project 'Ecosystem Research Wadden Sea'

\section{LITERATURE CITED}

Baird D, Evans PR, Milne H, Pienkowski MW (1985) Utilization by shorebirds of benthic invertebrate production in intertidal areas. Oceanogr Mar Biol 23:573-597

Beukema JJ (1981) Quantitative data on the benthos of the Wadden Sea proper. In: Dankers N, Kihl H, Wolff WJ (eds) Invertebrates of the Wadden Sea. Stichting Veth tot Steun aan Waddonderzoek, Leiden, p 134-142

Beukema JJ, Essink K, Michaelis H, Zwarts L (1993) Year-toyear variability in the biomass of macrobenthic animals on tidal flats of the Wadden Sea: how predictable is this food source for birds? Neth J Sea Res 31:319-330

Brey $T$ (1986) Formalin and formaldehyde-depot chemicals: effects on dry weight and ash free dry weight of two marine bivalve species. Meeresforschung 31:2-57

Burger $J$ (1984) Abiotic factors affecting migrant shorebirds In: Burger J, Olla BL (eds) Shorebirds - migration and foraging behavior. Plenum Press, New York, p 1-72

Burger J, Howe MA, Hahn DC, Chase J (1977) Effects of tide cycles on habitat selection and habitat partitioning by migrating shorebirds. Auk 94:743-758

Cezilly F, Wallace $J(1988)$ The determination of prey captured by birds through direct field observations: a test of the method. Colon Waterbirds 11:110-112

Cramp S, Simmons KEL (1983) The birds of the western Palearctic, Vol III. Oxford University Press, Oxford

Engelmoer M (1982) Distribution and feeding of waders at low tide. In: NOME (Netherlands Ornithological Mauritanian Expedition) (ed) Wintering waders on the Banc d'Arguin, Mauritania. Stichting Veth tot Steun aan Waddonderzoek, Leiden, p 101-133

Evans PR (1976) Energy balance and optimal foraging strategies in shorebirds: some implications for their distributions and movements in the non-breeding season. Ardea 64:117-139

Evans A (1987) Relative availability of the prey of wading birds by day and by night. Mar Ecol Prog Ser 37:103-107

Evans PR, Dugan PJ (1984) Coastal birds: numbers in relation to food resources. In: Evans PR, Goss-Custard JD, Hale WG (eds) Coastal waders and wildfowl in winter. Cambridge University Press, Cambridge, p 8-28

Flemming BW (1995) Zur Elastizität makrofaunistischer biosedimentärer Systeme im Spiekerooger Watt: Wechselwirkung zwischen Organismen, Sediment und Wasserkörper. First report Ecosystem Research Lower Saxonian Wadden Sea, ELAWAT project B6, Wilhelmshaven

Flemming BW, Ziegler K (1995) High resolution grain size distribution patterns and textural trends in the backbarrier environment of Spiekeroog Island (southern North Sea). Senckenb Marit 26:1-24

Glutz von Blotzheim UN, Bauer KM (eds) (1982) Handbuch der Vögel Mitteleuropas, Vol 6-8/I. Charadriiformes 1-3. Akademische Verlagsgesellschaft, Wiesbaden

Goss-Custard JD (1970) The responses of redshank (Tringa totanus (L.)) to spatial variations in the density of their prey. J Anim Ecol 39:91-113
Goss-Custard JD (1977) The ecology of The Wash III. Density related behaviour and the possible effects of a loss of feeding grounds on wading birds (Charadrii). J Appl Ecol 14: $721-739$

Goss-Custard JD (1984) Intake rates and food supply in migrating and wintering shorebirds. In: Burger $\mathrm{J}$, Olla BL (eds) Shorebirds-migration and foraging behaviour Plenum Press, New York, p 233-270

Goss-Custard JD, Jones RE (1976) The diets of redshank and curlew. Bird Study 23:233-243

Goss-Custard JD, Cayford JT, Boates JS, Dit Durell SEA. Le v (1987) Field tests of the accuracy of estimating prey size from bill length in oystercatchers, Haematopus ostralegus, eating mussels, Mytilus edulis. Anim Behav 35:1078-1083

Goss-Custard JD, Caldow RWG, Clarke RT, Dit Durell SEA Le v, West AD (1994) Population consequences of habitat loss and change in wintering migratory birds: predicting the local and global effects from studies of individuals. Ibis 137 (Suppl):(S)56-(S)66

Grotjahn M (1990) Sedimente und Makrofauna der Watten bei der Insel Spiekeroog. Untersuchungen im Rahmen des 'Sensitivitätsrasters Deutsche Nordseeküste' Forschungsstelle Küste 39:97-119

Herlyn M (1996) Zur Bestandssituation der Miesmuschelbänke des niedersächsischen Wattenmeeres. Mitt Norddtsch Natschutzakad, Schneverdingen 1:5-61

Hertweck G (1995) Verteilung charakteristischer Sedimentkörper und Benthossiedlungen im Rückseitenwatt der Insel Spiekeroog, südliche Nordsee. I. Ergebnisse der Wattkartierung 1988 bis 92 . Senckenb Marit 26:81-94

Hertzler I (1995) Nahrungsökologische Bedeutung von Miesmuschelbänken für Vögel (Laro-Limikolen) im Nordfriesischen Wattenmeer. Diploma thesis, University of Cöttingen

Hilgerloh G (1997) Predation by birds on blue mussel Mytilus edulis beds of the tidal flats of Spiekeroog (southern North Sea). Mar Ecol Prog Ser 146:61-72

Kuipers BR, Dapper R (1981) Production of Crangon crangon in the tidal zone of the Dutch Wadden Sea. Neth J Sea Res 15:33-53

Martin P, Bateson P (1986) Measuring behaviour - an introductory guide. Cambridge University Press, Cambridge

Meire P (1991) Effects of a substantial reduction in intertidal area on numbers and densities of waders. Acta XX Congr Int Ornithol, Vol 4, p 2219-2235

Meire P (1993) Wader populations and macrozoobenthos in a changing estuary: the Oosterschelde (The Netherlands). PhD thesis, University of Gent

Meltofte H, Blew J, Frikke J, Rösner HU, Smit CJ (1994) Numbers and distribution of waterbirds in the Wadden Sea. IWRB Publication 34, Wader Study Group Bull 74 , Spec Issue. Litotryk, Svendborg

Michaelis H, Obert B, Schultenkötter I (1995) Die Miesmuschelbestände der niedersächsischen Watten 1989 bis 1991 Berichte der Forschungsstelle Küste, No. 40, Norderney

Mitlacher G (1997) Ramsar-Bericht Deutschland. Schr Landschaftspfl Naturschutz 51

Moreira F (1994) Diet, prey-size selection and intake rates of black-tailed godwits Limosa limosa on mudflats. Ibis 136 : 349-355

Moreira F (1995a) The winter feeding ecology of avocets Recurvirostra avosetta on intertidal areas. I. Feeding strategies. Ibis 137:92-98

Moreira F (1995b) The winter feeding ecology of avocets Recurvirostra avosetta on intertidal areas. II. Diet and feeding mechanisms. Ibis 137:99-108 
Nehls G. Tiedemann R (1993) What determines the densities of feeding birds on tidal flats? A case study on dunlin, Calidris alpina, in the Wadden Sea. Neth J Sea Res 31: 375-384

McNeil R, Drapeau P, Pieroth R (1993) Nocturnality in colonial waterbirds: occurrence, special adaptations and suspected benefits. In: Power DM (ed) Curr Ornithol 10: $87-246$

Petersen B (1995) Nahrungsökologische Bedeutung verschiedener Mischwattbereiche im Ostfriesischen Wattenmeer für Watvögel und Möwen (Charadriiformes: Charadrii und Lari) während des Herbstzuges. Diploma thesis, University of Marburg

Pienkowski MW (1983) Surface activity of some intertidal invertebrates in relation to temperature and the foraging behaviour of their shorebird predators. Mar Ecol Prog Ser 11:141-150

Pienkowski MW, Ferns PN, Davidson NC, Worrall DH (1984) Balancing the budget: measuring the energy intake and requirements of shorebirds in the field. In: Evans PR, Goss-Custard JD, Hale WG (eds) Coastal waders and wildfowl in winter. Cambridge University Press, Cambridge, p 29-56

Piersma T, De Goeij P, Tulp I (1993) An evaluation of intertidal feeding habitats from a shorebird perspective: towards relevant comparisons between temperate and tropical mudflats. Neth J Sea Res 31:503-512

Reise K, Lakschewitz D (1998) Benthos des Wattenmeeres zwischen Sylt und Rømø. In: Gaetje C, Reise K (eds) Ökosystem Wattenmeer-Austausch-, Transport- und Stoffumwandlungsprozesse. Springer, Berlin, p 55-64

Rösner HU, Prokosch P (1992) Coastal birds counted in a spring-tide rhythm - a project to determine seasonal and long-term trends of numbers in the Wadden Sea. Neth Inst Sea Res Publ Ser 20:275-279

Scheiffarth G, Nehls G (1997) Consumption of benthic fauna by carnivorous birds in the Wadden Sea. Helgol Meeresunters 51:373-387

Scheiffarth G, Nehls G (1998) Saisonale und tidale Wanderungen von Vögeln im Sylt-Rømø Wattenmeer. In: Gaetje C, Reise K (eds) Ökosystem Wattenmeer-Austausch-, Transport- und Stoffumwandlungsprozesse. Springer, Berlin, p 515-528

Schmidt S (1998) Raum-Zeit-Muster häufiger Laro-Limikolen zur Zeit des Herbstzuges im Spiekerooger Rückseitenwatt in Abhängigkeit von Sedimentzusammensetzung und Nahrungsangebot. Diploma thesis, University of Oldenburg

Editorial responsibility: Otto Kinne (Editor),

Oldendorf/Luhe, Germany
Smit CJ (1980) Production of biomass by invertebrates and consumption by birds in the Dutch Wadden Sea area. In: Smit CJ, Wolff WJ (eds) Birds of the Wadden Sea. Leiden, Balkema, Rotterdam, p 290-301

Ssymank A, Dankers N (1996) Red List of biotopes and biotope complexes of the Wadden Sea area. Helgoländer Meeresunters 50, Suppl., 9-37 and: Schr Landschaftspfl Naturschutz 47:9-37

Swennen C. Leopold MF, Stock M (1985) Notes on growth and behaviour of the American razor clam Ensis directus in the Wadden Sea and the predation on it by birds. Helgol Meeresunter 39:2155-261

Tiedemann R, Nehls G (1997) Saisonale und tidale Variation in der Nutzung von Wattflächen durch nahrungssuchende Vögel. J Ornithol 138:183-198

Wahls S (1995) Räumliche und zeitliche Verteilung des Kiebitzregenpfeifers (Pluvialis squatarola) während des Herbst- und Frühjahrszuges im niedersächsischen Wattenmeer. Diploma thesis, University of Oldenburg

Yates MG, Goss-Custard JD, McCrorty S, Lakhani KH, Dit Durell SEA Le v, Clarke RT, Rispin WE, Moy I, Yates T, Plant R, Frost AJ (1993) Sediment characteristics, invertebrate densities and shorebird densities on the inner banks of The Wash. J Appl Ecol 30:599-614

Zang H, Großkopf G, Heckenroth H (1995) Austernfischer bis Schnepfen. Naturschutz Landschaftspfl Niedersachs B, $\mathrm{H} 2.5$

Zwarts L (1991) Seasonal variation in body weight of the bivalves Macoma balthica, Scrobicularia plana, Mya arenaria and Cerastoderma edule in the Dutch Wadden Sea. Neth J Sea Res 28:231-245

Zwarts L, Drent RH (1981) Prey depletion and the regulation of predator density: oystercatchers (Haematopus ostralegus) feeding on mussels (Mytilus edulis). In: Jones NV, Wolff WJ (eds) Feeding and survival strategies of estuarine organisms. Plenum Press, New York, p 193-217

Zwarts L, Wanink JH (1991) The macrobenthos fraction accessible to waders may represent marginal prey. Oecologia $87: 581-587$

Zwarts L, Wanink JH (1993) How the food supply harvestable by waders in the Wadden Sea depends on the variation in energy density, body weight, biomass, burying depth and behaviour of tidal flat invertebrates. Neth J Sea Res 31 : $441-476$

Zwarts L, Cayford JT, Hulscher JB, Kersten M, Meire PM Triplet $P$ (1996) Prey size selection and intake rate. In: Goss-Custard JD (ed) The oystercatcher: from individuals to populations. Oxford University Press, Oxford, p 30-55

Submitted: February 4, 1998; Accepted: November 18, 1998 Proofs received from author(s): February 25, 1999 